\title{
The Unconscious Self in Role Playing Video Game's Avatar
}

\author{
Ardian Indro Yuwono, Gabriel Roosmargo Lono Lastoro Simatupang dan Aprinus Salam \\ Departemen Ilmu Komunikasi Fisipol Universitas Gadjah Mada \\ Departemen Antropologi, Fakultas Ilmu Budaya, Universitas Gadjah Mada \\ Departemen Sastra Indonesia, Fakultas Ilmu Budaya, Universitas Gadjah Mada \\ Email: ardianindro@gmail.com \\ Email: lono_simatupang@yahoo.com \\ Email: aprinus@ugm.ac.id
}

\begin{abstract}
Abstrak
Dalam bermain video game, manusia direpresentasikan melalui berbagai jenis avatar. Beragam bentuk avatar dalam role playing game diciptakan oleh para pemainnya. Proses penciptaan avatar tidak bisa dilepaskan dari ketidaksadaran pemainnya, hal ini meliputi hasrat, ego dan ideologi. Penciptaan avatar ini tidak berhenti dan selalu berproses selama bermain video game mengikuti narasi. Segala keputusan, jalan dan tindakan yang diambil oleh pemain akan berpengaruh terhadap perkembangan avatarya. Pada akhirnya avatar selalu menjadi manifestasi dan refleksi atas ketidaksadaran pemainnya. Riset ini dilakukan menggunakan metode etnografi dan teori psikoanalisis Jacques Lacan.
\end{abstract}

Kata Kunci: video game, pemain, ketidaksadaran, etnografi

\begin{abstract}
In the world of digital video games, human players are present through surrogates. Surrogates in the video game is a character which also called by the term avatar which is a self-representation of real players. The presence of avatars in role playing games are formed through a process of creation by the gamer. The production of avatars cannot be separated from the unconscious mind of the players, the unconscious desire, ego and ideology. This avatar creation process continues ongoing, following the progress of the video game story. The decision, the path, and the act that the player take in completing the story are gradually reshaping the avatar. In the end, the avatar eventually became a manifestation and reflection of the unconscious minds of the video game players. This research conducted using ethnography and Jacques Lacan psychoanalysis theory.
\end{abstract}

Keywords: video game, player, unconscious, ethnography 


\section{Introduction}

As a gamer, I had never been introduced to video game directly. Mama, the way I called my mother, was not only once or twice being angry with me because of video game. It started when I was in primary school until I graduated from college. Expressions like "video game makes you stupid", "what do you want to be if you only play video game?" and "you just waste your time by playing game" are only few examples said by my mother considering with my introduction between me and video game. Playing video game has never been normal according to my family's perspective and negative expression relating to it is a regular phrase my parents always say. However, what is actually a gamer looking for in playing video game?

Playing video game is an individual activity into accessing the text interactively, such as accessing new media like internet and operational system in various hardware. Fundamentally, accessing video game has the similar activity as accessing movie, in which access is drawn to follow the narration or story. Narration and story that written in video games are alike in a movie, through script writing to audio visual execution also visual effect and music. However, beside its interactive element, there is basic difference between accessing video game with movie, in which in a movie, audience has limitation only to the reality and director's point of view (through camera person), while in video game, players tend to have freedom to create their own narration considering the rule and limitation. Flitterman-Lewis (2005) in his research tries to position TV audience as movie audience borrowing Metz's (1982) idea which discuss the unconscious structures that underlie our experience of film, noting how the powerful impression of reality in cinema is first and foremost an illusion.

In Flitterman-Lewis's idea (2005), watching TV is not only accessing narrative text or story but also finding audience to the "perfect form" that is being represented by fictional characters into the television. As an audio visual production that has focus on story or narration, movie has a similar characteristic. This perfect form is said by Flitterman-Lewis (2005) as mirror phase concept belong to Jacques Lacan. This perfect form finding by the TV and movie audience is for instance similar to a baby gazing into the mirror to find their perfect "others".

From all of various genres in video game, Role Playing Game (RPG) is a genre that mostly gives full freedom to its players. It is called as "Role Playing" because when players play this game, that person has a freedom to create a character that can represent desire, passion, satisfaction, or at least proximity with other players. Beside character's design, character development and story also depend on various choices taken by the players so that content in the video game can be changed dynamically, though there is still limitation (Harrigan, P., WardripFruin, N., Crumpto, M., 2010).

Video game differs its content with television and movie, in which the decision in producing the narration are not only be given by the developer but also the player. In video game, players are given variety of choices to build his content of narration. In RPG genre video game titles, players are free to create and choose their own character more over they are able to alter the storyline. The choices and creation of various characters, role models and figure are the process of player embodiment into video game text which is going to be their avatar and representation in the virtual world of video game.

The embodiment of player in the text video game is the mirroring or reflection process which has been stated by Flitterman-Lewis (2005) as when the audience is seeing the fantasy from the TV and cinema. According to Flitterman-Lewis (2005), Freud says that when the audience watch a fantasy in a television and cinema, it is part of fulfilling process or desire by imaginary space as the main character (protagonist). This imaginary space is similar to what has been said by Lacan (1949 in Hepburn, 2003) with the mirror phase as a part of human unconsciousness to the others that are different, others that are more "ideal". 
This research aims to understand how the gamers interpret their self in playing video game as a part of their life through the unconscious process by reflecting themselves through the avatar inside the video game. This research chooses active (on-going) gamers as the subject to see how video game becomes part of their lives, how video game contributes and influences their lives so far. This research also unravels what kind of experience that is received to their existence of their lives either individually or socially. The purpose of the research is to see how the gamers understand playing as unconscious reflection from Lacan's perspective.

\section{Research Method}

This study is conducted using qualitative approach and ethnography method in cultural study framework developed by Paula Saukko (2003). Saukkos's Etnography method developed has two main purposes that are unraveling the truth in understanding experience that is owned by the subject and learning the concept that is used in categorizing that experience.

\section{Result and Analysis \\ Gamer and Play}

In differentiate the type of player in video game, the general category commonly used in video game culture is casual and hardcore player (Fron et al, 2007; Juul, 2009; Rigby \& Ryan, 2011), which hardcore players is considered as majority group in video game player demography (Fron et al, 2007; Kafai et al, 2008; Juul, 2009). Contextually, the terminology "hardcore" in the gamer demography has meaning as the active and committed player group in the video game. Fron et al (2007) and Juul (2009) argues that genre preference has vital contribution to the grouping of hardcore gamer. A hardcore gamer tends to like video game that has fantasy themes such as science-fiction or magic arts and swords that need full attention and longer time to play (Fron et al, 2007; Juul, 2009). Hardcore gamer also tends to be fond of video game with narrative norm and the rules that are relatively conservative in which the video game space is placed on screen
(Aarseth, 2004; Mayra, 2008; Juul, 2009; Rigby \& Ryan, 2011). At last, hardcore gamer likely to be fond of video game with higher level of difficulty (Juul, 2009). Thoroughly, video game prone to be liked by hardcore gamer can be classified as serious video games.

The level of high intensity of playing is also the feature of hardcore gamer (Cassell \& Jenkins, 1998; Fron et al, 2007; Juul, 2009). It is because video game has low interruptible level which means that a gamer has to play the video game up to the particular level before he is able to stop to play or the progress that he has made cannot be saved (Juul, 2009). Especially, it happens when online video game needs internet connection to the server. An online video game mission such as Tom Clancy's Division or World of Warcraft needs intense collaboration among players and it is usually time-consuming to play. Moreover, the players cannot save their progress at all, therefore as a consequence they can only finish gaming session after finishing all the mission. This matter is obviously without no consequence.

The first consequence is that the hardcore gamer tends to override various activity that has no connection with gaming such as school, job, society, family, and socializing in general (Griffith \& Davies, 2005; Rigby \& Ryan, 2011). In the extreme level, this ignoring action to the things that has no connection with the gaming will lead to breaking professionalism, intrapersonal, even to their own health (Griffiths \& Davies, 2005). Finally, this emerges various stereotype relating to the gamer and video game.

The second consequence is that there is a hegemony to play (Fron et al, 2007) by the hardcore gamers in a gaming culture (Fron et al, 2007; Cassell \& Jenkins, 2008; Kafai et al, 2008). This hegemony is especially seen through the "unfriendly" action to the casual gamer or inclusive activists to the video game culture in which they think it is a threat in playing hegemony (Fron et al, 2007; Cassell \& Jenkins, 2008; Juul, 2009). One of the popular examples are bullying action to Anita Sarkeesian after she 
starting a movement through video serial web to fight against the representation of woman in video game that is homogen and full of sexual exposure (Kolhatkan, 2015). As a result, a group of hardcore gamers feels knocking out and antiphatic to the video game (Fron et al, 2007; Kafai et al, 2008).

Juul (2009) also states that a hardchore gamer needs big sacrifice to play the game, especially time. If the casual gamers spend only spare time to play (for example: waiting for the public transportation by playing game), the hardcore gamers are the opposite since they have to allocate/dedicate their time to play the video game (for example: reduce the sleeping time to be able to play the game). This thing can be influenced by the type or genre of the game being played, in which hardcore game is indeed demanded to be more complex and creative to finish the game.

Huizinga (1955) mentions that the game is one of the basic of a civilization. Various aspect development into the human civilization such as religion, law, social structure, and culture is formed and decided by playing game. Even, Huizinga says that the development of human culture depends on the playing experience rather than of rationale thought. Taken as an example, Huizinga says that Ancient Greek culture that was inspired from the spirit and process of playing. Huizinga sees that dialogical activity in the Plato philosophical framework to the Ancient Greek civilization at that time considered as a form of playing. Permenides, one of the figure that became the dialogical counterpart at that time, stated that philosophical dialog was a form of asking question games and when he was asked about his philosophical perspective relating to the human existence, he said that those questions were difficult to play. Another example is from the Ancient Greek culture that had relation with playing process that was the host of Olympic Tournament, in which this Olympic became the pioneer and inspiration to the other tournaments and competitions that paid respect to the value of fairness and sportsmanship. According to Huizinga, playing and human culture are connected each other and cannot be separated to each other (1955).

Relating to the explanation what the game is, Huizinga (1955) explains that there are five characteristics in games. First, playing is an act that is willingly done (voluntary activity) and an expression of freedom. Freedom, in this matter, is someone that can be free to do playing activity, and playing around that is a process of expressing the meaning of freedom form someone. Second, playing is an activity that can be done in daily activities (ordinary life). Playing, in this case, is a process to enter "other" world that has own rules and limitation. In this case, Huizinga takes an example using "playground" concept and its characteristics can be in a sacred place (or with religious space; mosque, church, monastery, etc.). This place and has own rules and limitation that coordinate all of people inside. Third, playing has its own space and time. The process of playing has plot that determine when the process begins and ends.

The process of playing is an activity that is based on the use of rules and "unique" limitation, that play with space, idea about time, costume, and various tools and devices. Fourth, the process of playing through creating order (order that demand the player that rule the players to follow the rules). At the most process of playing, these rules and orders are absolute. If the player does not follow the rule, therefore the player will break the order and process of playing itself. Fifth, playing is a social activity that connects various individual background and social group in the middle of society structure. Though, it is true that Huizinga denies that the process of playing is done functionally to fulfill social need.

He states that playing can be alone. Playing is an activity from the organism that understands the meaning of self-action and others (Rodriguez, 2006). Therefore, playing activity is not only limited in biological mechanism or using logic reference. However, it is also a supralogic activity that is not only based on thought 
of causality. In short, playing is done not to have something else, but to play the game itself. Hence, Huizinga explains that paying is a free and meaningful activity, based on space and time regardless from daily routines, tight ruled and limitation that are demanded and absolute. It is also a social activity, done to play the game itself (Rodriguez, 2006). The process of playing by using those five characteristics forms separated space from daily routines. Huizinga mentions that space as a magic circle. These physical forms can be found in daily activities such as chess board, boxing arena, stadium, concert hall, the altar, and many more. These spaces also have clear limitation in which this game begins and ends that show the process of playing as a temporary interruption from daily routines. The magic circle existence has relation with rules and artificial limitation that are valid in the process of playing.

Huizinga (1955) sees that by entering the 21 th century, those characteristics are faded away. Being forced by industrial revolution, modern culture pushes human to have industrial business orientation. To push the quantity of product quality that is advantageous, human, in this modern world, is demanded to have higher work ethic and to avoid playful characteristics. Human in this modern world is also pushed to follow the mindset in an empiric paradigm, scientific, and technocratic that end in instrumental rational mindset. This instrumental rational mindset only concentrates on ways, paths, means, and instrument. Those are the most practical and effective to get the best result or goal without considering moral, ethic, and aesthetic aspect. Therefore, how can we see "playing" in this recent century much more modern in which the space is changed in a digital space (video game)?

Video game is one of the popular entertainment nowadays (Fron et al, 2007; Mayra, 2008) because of socio-technology that is possible to be accessed in large demography (Cassel \& Jenkins, 2008; Juul, 2009) and intimacy as a result of the tendency of fulfilling three mains human intrinsic that are competency, autonomy, and connection through player and video game players (Rigby \& Ryan, 2011). In addition, video game is also associated with playing culture as an effect from its location in a magic circle with the mechanism along with separated rules from daily activities (Aarseth, 2004; Mayra, 2008). However, the culture of the playing is an independent concept that is not always connected in video game and it has big implication. Therefore, what is "playing"?

Playing is an activity that is attached in human culture since the early civilization (Mayra, 2008). Even, the aspect of life such as career or education has various elements and it is parallel to the other elements such as challenge, strategy, and skill that relate to the success (Mayra, 2008). As conclusion, playing is an activity in free time with the similar intensity with career or education (Huizinga, 1955; Salen \& Zimmerman, 2006).

After discussing the significance of playing, the next question is that how we formulate playing systematically? What are included as playing activity? Despite of the magic circle (Huizinga, 1955) as a life simulation (Baudrillard, 1998), the basic difference between playing and the other aspects of life takes place to the willingness (Goldstein, 2005; Bogost, 2010). Playing is an activity that is full of willingness and if the willingness is taken off from the game, therefore it cannot be called as playing (Goldstein, 2005).

From that definition, playing, in a basic level, is a free activity (Caillois, 1961). Being different with working or education that has clear definition, playing is wide and abstract. Playing is also psychical and/or psyches and also has flexible goals and rules compared with career or education. Segregation is between life and playing (Huizinga, 1955; Mayra, 2008) supported by Caillois's argument (1961) saying that playing is ruled by rules that are outside the laws from molecular and conventional world (Rigby \& Ryan, 2011) or what is so called "real world".

Another form of unbounded playing to the conventional laws is the intensity of the 
player that has an important role. As an example, player 1 is as a knight and player 2 is as a dragon although in the eyes of others who have not been included in a game consider player 1 and player 2 still as human. This fact is formulated by Caillois (1961) that playing involves fantasy in which the roles are experienced truly at least in psyches. Aarseth (2004) and Kirkpatrick (2009) strengthen that argument by saying that there is fetishism in playing. It means that a player only focuses on the attention to the playing space either kinetic as in a traditional game; and in a space other than not getting high attention from the player.

Last, playing is associated by positive feeling (Caillois, 1961). Rigby and Ryan (2011) says that this association is tightly related to the intrinsic need that is fulfilled through playing; playing video game in the context of their writing. Playing can fulfill the basic human right to the competition, autonomy, and its relation that is almost instant and its balanced proportion (Rigby \& Ryan, 2011). As a comparison, real world activity or education needs longer time to fulfill those three intrinsic needs; moreover, there is no guarantee that they can be fulfilled (Rigby \& Ryan, 2011). Encountering the second decade in the 21th century, integration of playing to the aspect of life that is normatively considered more seriously is a developing phenomenon (Kapp, 2012).

\section{Unconsciousness and Mirror Phase}

Talking about unconsciousness in psychoanalysis cannot be separated from these two experts in psychoanalysis that are Sigmund Freud and Jacques Lacan. Freud succeeds to build basic foundation that "full form of self" is determined by unconsciousness and also the repression of his desire. Where ego as "I" is a product of repression from super ego to id that results to need and reality. Desire is an id that is not achieved, while reality is an ego that is experienced by the subject in his daily life (Eagleton, in Flitterman-Lewis, 2005). According to Freud, ego is no more than a negotiation process between unconscious desires with various social elements and cultures (Hepburn, 2003; Bracher, 2003).

By understanding a self as an "ideal self", Freudian psychoanalysis leads us to know that ego is the manifestation of consciousness which always restrain the unconsciousness (Hepburn, 2003). In various references, Freud says that "woe es war, sol ich warden" (if there is an id there is "I", ego). Therefore, it can be said that Freudian psychoanalysis goal is to position ego as a consciousness as a result of repression to id.

Freud's statement about ego and ideal self are rejected by Lacan who considers ego as an imaginary product of unconsciousness, so that straightly Lacan states that ego or self is only illusion. Lacan understands that unconsciousness is as an entity that has a structure. To strengthen his statement, Lacan combines traditional psychoanalysis with Saussure's and Derrida's idea. Lacan connects the unconscious structure with the signified-signifier relation. Various elements in the unconsciousness in the form of need, desire, and image create signified-signifier that forms "chain of signifier" meaning that a signifier has a meaning only when it is not for another signifier (Bracher, 2003). Lacan says that there is no signifier that directly refers to its signifier and he simply uses metaphor dictionary as an example in which a word always refers to another word and it cannot refer to something that should be defined by that first word.

On the early psychoanalysis stage, Lacan agrees with Freud who says that human is only a flash of meat who has no identity even without proper understanding about himself as a full entity. Principally, in the beginning of his life, human is moved by various needs so that it is difficult to recognize the object as a full entity even he will be difficult to differ between himself and an object that is being faced (Bracher, 2003).

As the baby grows, he (the baby) slowly understands the difference between him and his mother (satisfied object) and slowly makes a gap with her and at the end it lost and separated. At first being a need, right now it becomes a 
demand. The demand happened in this phase is not a demand that can be satisfied by various objects, however the demand of relation by the others is love, care, and recognition that is never satisfied. The baby who realizes that his entity is an object outside himself starts to construct his idea about otherness that is entity "outside

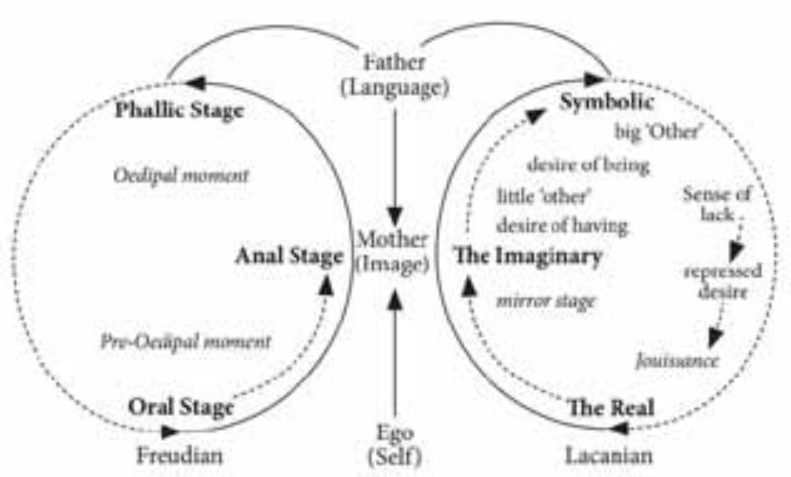

The differs between Freud and Lacan concept of understanding desire in psychoanalysis (Wijaya, 2015)

Lacan (in Hepburn, 2003) writes this phenomenon as a mirror phase that is the baby starts to see his image on a mirror and recognize his shadow into that mirror as himself. The baby realizes that there is another entity on the mirror and he assumes as "I as a full form". This image is defined as an ideal ego by the experts of psychoanalysis and it is formed as a result individual imagines a "self" in a full form, stabilized, and united without lack. This fiction is created as a compensation of losing in the previous stage. Whereas, the image that is in the mirror is otherness that is wrongly precepted as "I".

Lacan mentions that mirror phase is in imaginary area because the image about self is created through identification process of imaginary image on the mirror as an ego, whereas that image is otherness that is more stabilized from "I". Every individual of baby imagines/ wants unity of himself with the otherness and the most important otherness is his mother and his image that he sees on the mirror. At the beginning Lacan sees this mirror phase as only in a baby phase but in its development, this phase is developed in various forms.

In this recent modern phenomenon, media can be a "mirror" in a modern human mirror phase. In a film and television, imaginary fantasy is produced by the content or the story line that is moved according to the shadows that we want (Metz in Flitterman-Lewis, 2005). This idealized character negotiation during this movie is shown always happening and this is that is called Lacan as a mirror phase. Of course, this matter happens because of acceptance to the illusion that is presented on screen.

Treating video game player will be different with treating movie audience that has tendency to be passive and active in the certain limitation. Jean-Louis Baudry in FlittermanLewis (2005) says that human unconsciousness connects with "various dreams" that happens when they watching movie. Audience "produces" desire through protagonist characterization as a result of their unconscious "dream". Baudry (in Flitterman-Lewis, 2005) agrees that audience can get the sensation because of various elements starting from technical (such as audiovisual effect), text narration in a structured form, audience position when accessing the movie, and audience "mental machine" condition subjectively (conscious and unconscious).

In a video game study, FlittermanLewis' (2005) theory is no longer relevant. The comparison between audience and player is in a very different level. Although in seeing the technical and narration might be similar. The main difference is that the "mental machine" consists of unconsciousness and consciousness of the player working on interactively space and in a longer time. In playing video game, negotiation that happens does not only stop in the mind but also will be "rewritten" by the player into the video game narration being played. The rewriting activity that is done by the player is part of the subjectivity and unconsciousness of the player. "Dream" that is said by Baudry, as a part of "mental machine" can be projected/ reflected through avatar and various choices that 
have consequences that are chosen in the video game narration (Baudry in Fliterman-Lewis, 2005). This rewriting process will give different perception, negotiation, and conclusion among one player into other players though in the same video game.

\section{Self: Outside and Inside of Video Game \\ 1. Subject David, Surabaya. I am the Perfect One.}

As a married man, having one kid, and financially free, subject David tells many things about relation and his story with video game. The introduction with video game started in the early 1990s when he had a hobby playing at Arcade Centre in Tunjungan Plaza, Surabaya. David's parents had never forbidden him to play video game as long as he had finished his school tasks. Even more, he had joined video game competitions called "Street Fighter" and had won it. As a kid who grew up in an upper-class family, David's access to a video game had never got a difficulty.

David told that he has never been obsessed with video game and he wants to be understand that he is having a proper hobby just like the others while having fun with watching movies, reading books, or even spending time to go on a vacation. Playing video game does not make David becoming anti-social, on the contrary he gets many friends in Arcade Centre in Tunjungan Plaza.

In his journey, some things changed, David does not play video game in Arcade Centre anymore, instead he brings those video games home. David's parents bought him all of the video game devices that he needs starting from console to advanced personal computer (PC). From this daily custom, David transforms into a technology enthusiast who always owns all of the new technology in video gaming. This condition continues up to now. Even, he tells that he has to be "showing off" to his family and friends that he knows everything about technology.

"I, among my family and friends, am known as an IT expert. While me as a gamer is more exclusively only for the closest people who knew me well. For me, if there is a new technology, I have to know it first because I feel ashamed if being asked but I have no idea. Those people will consult me about technology, believing in me." (David, 35)

This "proudness" is based on David's idealism that comes from his unconsciousness in which Lacan mentions that this is a symbolic phase. David tries to be accepted as a self (who knows technology) by erasing "big other" or usually called "symbolic father" otherness (Lacan, 1997). One of his way becoming "the most knowing person" about video games, gadget, and other technologies is by buying all of the console product of video games that has been released from the first-generation Atari up to the recent generation Xbox One and PlayStation 4, along with the newest PC game and high end cellular phone Samsung. David is able to purchase as basically he is from a rich family and right now he replaces his father's position as one of the owner of the big building construction company in Surabaya. That is why David has "free financial" that, makes him easy to purchase everything as his pleasure of the repressed desire. Freud (1963) says that Id as desire that is always repressed by super ego in which David's case is no longer strong to repress id and it is because of the free financial experienced by David.

For David, playing video game is not only a matter of pleasure but also a "wild fantasy" that cannot be created by only watching movie or reading a book. This wild fantasy of playing the video games is differed with while we are watching a movie or reading a book, that according to David in playing video games a person can create the fantasy and "living" in it.

"It is different between playing video game and watching movies, I love to watch action movies but, I only create an imagination in my mind by thinking of it 
not living in it. If I play video game I can be anything I want, and most importantly I am satisfy using and creating a character that is so me." (David, 35)

The self-image in a video game cannot be cease only for the character or the avatar that he likes. David's opinion about "can be anything" in video game he shows in some game titles that has feature to do character design manually. For David, it is important to be his own self that he will design his character that is very similar to his personality.

"in video game, it is possible to design and create any kind of character such as in GTA 5 or various other RPGs and I will design the similar with my being but it will be better and cooler. For example, its appearance has punk hair and tattoo that becomes significant because it is impossible for me to have punk hair in a real life, moreover wearing tattoo that I don't want to use it. The most important thing is that if it is being seen by other gamers, my character should be chill". (David, 35)

From what has been said by David, basically he likes to see himself using tattoo and colorful punk hair, but there is a consequence that he has to face if he has those characteristics in a real world he will get social judgment. The social judgment is that he will get punishment because he is the leader of a company, as a Moslem, and of course as a Javanese that has Javanese norms. This phenomenon is actually the same as Lacan's say that video game is a "mirror" making David otherness "full form" (Ruti, 2010). This is also what has been said by Freud (1963) about the repressed desire that is no longer relevant it is because of ethic and norm that is in a video game world has changed.

As a video game player who often play online game with the other players, David's personality cannot be separated from the real world he is experienced. All of the things in the virtual world in video game and real world that is connected.

"When I play online game, I must play as an alpha, even more if my level is high. There is no case that I follow other players, they should follow me no matter what. I like to use knight character along with shiny clothes and I must be a leader. If it is possible I will buy that clothes and the stuff in download content so that it is completed." (David, 35) "I named my daughter, Yuffie because I like its character in Final Fantasy and I want the others know about that. My hope is simple that later Yuffie will enjoy video game and we will play together". (David, 35)

For David, trying to be a leader in an online video game is a must, however it is actually part of the unconscious world. In some ways, David always wants to be the central character even in his real life, starting from his figure as a father and decision maker at home replacing his own father, as a company leader, and claimed himself as IT experts among his family and friends. It can be said that the David's real life influences his style of playing. On the other hands, David represents himself as a full character. On the other hands, David also represents himself as a full form to show it to others that he likes video game, for example by having Yuffie as his kid's name and the amount of money that he has spent only to buy software in video game. The representation of David in video game happens continually through 'fantasy' and 'reality' that he has been experiencing in a real world into the narration that he writes in video game through the chosen character. If Flitterman-Lewis (2005) says that audience experiences fantasy such as dream, therefore fantasy in video game is held continuously.

In playing video game, unconsciousness does not only stop into the character design as 
the representation of the player, but also to the choices of video game narration that is chosen by the player. David, as the lover of action and blood genre, does not want to be an antagonist in his game.

"If I'm faced to many choices of RPG, I will not be a villain, moreover, if it is my first play through. My choice is always an advantageous decision and I avert becoming a person who is hated if being with others" (David, 35).

When offered to the choice of consequences, it can be concluded that David averts to be villain or bad character. What has been said by Freud (1963) about repression to the id does not happen to David as he says that being a protagonist is not because of the real-life norms but more to the perfection. For David, perfection in a story and character development will be achieved if his character is good, and his reward will be reached if he chooses to be protagonist. Some things that are important are the access to the ending of a good narration, usually called as true ending or good ending. David's condition is a pleasure of expectation (W.R., 1835), that he imagines that video game must have a happy ending so that there are no questions left and can influence the satisfaction to the narration that is being played.

\section{Subject Johannes (Jo), Yogyakarta. Moral Value is Important.}

The second subject is Johannes (Jo), single, who works as an IT worker so that he has good financial. Jo has told that he has been playing video games for more than 20 years. Starting from primary school up to the high school, he had spent his time by playing video game in eight (8) to ten (10) hours per day, as a result his social life had changed because he was always in his room. When he was in college up till now he is a worker, Jo's pattern to play video game also has changed in which it does not reduce but increase along with sacrificing his sleeping time. Jo comes from the upper-class family and in a basically moderate catholic.

Jo considers video game as the essential part in his life that he was introduced to video game when he was 4 years old. As many other busy families in Jakarta, Jo was bought Sega so that he could stay at home after school because his parents actually want him to be at home as a result Jo has an access to the video game widely. In his daily activities, he locks himself in his room and is busy with virtual world in video game. This activity has been continued until he has been working recently.

"In my opinion, I might be obsessed or eve addicted in playing video game. I feel like this game is part of my life. If I am not allowed to play game, I cannot do that. Right now, I have been working but playing game does not frequently reduce instead it increases, moreover I have enough money to fulfill my satisfaction in playing game". (Jo, 27).

Ideologically, playing video game is different with the time when he was still a student, the fundamentally difference is the capability of playing original and he is proud about it. According to Jo, in the past he bought bootleg version of video game whereas right now he would only buy the original one. After working in an IT company, Jo feels that designing and creating software, digital applications and computer programs is a difficult challenge, which bring him realizes that respecting original works are very important.

"When I buy original video games from Steam it does not only mean I support the developer. It means that this is my milestone, my achievements which lead to fulfill my satisfaction. At this point I knew that I was doing right and on the right track, I love playing game and I am capable to support it with my own hand. Video game has been part from me for a long time and my act here is necessary to 
show how important a video game is to $m e "(\mathrm{Jo}, 27)$.

In buying original video game titles Jo shows how serious he was with video games, he spent approximately 4 billion rupiah just for video games. The satisfaction of desire which Freud (1963) states as the ego, formed in the shape of fulfilling the having and playing video game as desire by letting go the repression of financial issues as the "control". While according to Lacan (1997), this situation represent how Jo are willingly to be admitted that he can stand on his own in living his relationship with video game, detached from being to blame on spending huge amounts of resources in video game.

In representing himself in video game, Jo always takes positioned himself as a male and he always playing a role as a good antagonist. Indirectly, he tries to show his dominance that is different with his real situation.

"I am fans of Final Fantasy but I don't play the 13th version of that game since the main character is a female. I don't play some of the game such as Lara Craft because the characters are female although the story is good by giving it 9 as a rate. For me, in playing video game I must use a male character since I am a male, aren 't I?" (Jo, 27)

According to Jo, playing as a male character is very important in playing video game. In his real life, Jo is not a popular guy especially among girls since during his life most of people see him as a video game junkie. This situation happens as in his real time, Jo has failed to position himself as a full form and fulfill what has been said by Lacan (1997) as the big 'O' or desire of being. This also happens what has been stated by Freud (1963) about repression to the id in which Jo tries to release it through video game and he always takes the dominant man as his character. Jo has no role play in his social life making him doing mostly withdrawal when his friends gather.

"When I was a student, I was lazy to hang out with my friends since I had no money. Nowadays, if my colleagues hang out, it turns out that I tend to be not to join them; it is like wasting time to chitchat. What will be discussed? We have already met in the office and we have talked already. Watching movie or eating out is only wasting our money. My time is for gaming especially on the weekend I can play until dawn, I do not care about time anymore." (Jo, 27)

Jo often does withdraw from his surrounding because he considers that building relation socially does not important nor significant to his life. On top of them, Jo arranges to make use of any all resources he has into to video game, not for chilling and hang out or any other social use.

There is something unique about Jo when he plays the video game that is when modern RPG almost have free feature to do anything starting from the harassment up to sexuality, he rejects them. This feature is prepared along with its story line; even some of them decide the story plot. For Jo, playing video game is different with watching movie or accessing pornography. Jo considers that pornography should not be needed in a game at least he will not take that option.

"Although I rarely going to the church, but for me a marriage is a sacred moment. Sexual intercourse should be with our spouse in a marriage bond. If I watch JAV (Japanese Adult Video), I only watch it without any feeling, but this is game. That's the character that I create, and that character is me and I don't want to have sexual intercourse even if it is only in a game. The same with the harassment, I will not take the position as a bad man because I do not enjoy that. If I become evil accidentally, I will restart my game." 
(Jo, 27)

In Jo's case, the existence of religion holds the significant role toward his life. He holds Catholic's values that he has gotten since childhood. This is what Freud means (1963) in his theory in which sexuality as an id repression by a religion that has a role as super ego. However, it will be different if it is seen from Lacan's perspective that a marriage may be the highest manifestation that is got from human from their relationship and sexual intercourse exists because of marriage. In this perspective, Jo actually is in the mirror phase in which he tries to create his full form in the video game and to create himself in a more perfect relationship among other humans.

\section{Conclusion}

This study analyzes two subjects who have "job" as a gamer and have been playing for more than ten (10) years with the high intensity of playing. Both of the subjects are David (man, married, building construction owner, Surabaya) and Johanes (man, IT, Yogyakarta). The choice of these two subjects is based on the decisive conceptual that is written by Bernard (1994) that is a person tells a story in a casual way and also understand about the information that is needed. In this study, subjects are given the focus to tell a story relating with their experiences and their process in playing the Role-Playing Game.

Although playing video game can be claimed as the consciousness in a human when following the story and its narration, the process cannot be separated with human unconsciousness. Without being realized, David and Johanes (Jo) play the video game with their unconsciousness. Jo, for example, always holds the Catholic's values and David always represents himself as a leader. This unconsciousness emerges as a result of releasing the repressed desire into the virtual world and also an effort from the subject to see themselves to be in a full form through video game avatar. When a player takes the decision in video game that seems to be random, basically he is not but reflects it to the experience in a real world.

Another finding in this study is that the actualization and reflection in video game is very personal, subjective, and maybe it will never be the same in one invidual to another. All of the perspectives in RPG video game depend on their players on how the player wants to finish or create the story. The story line in video game allows the player "writes" their own dream that should be perfect through the avatar/character and the decision being made.

However, whatever player's opinion and responses, they cannot avoid reflecting their unconsciousness while playing about the meaning of a full form through the language of visual images of the avatar they created yet mirrored. Lacan claims that the desire of the subject and the other in the mirror cannot be distinguished, so that the subject often mistakenly identifies: the other is considered his/her self, while his/her self is considered the other. This is the reality of otherness in Lacan's perspective that serves as a pleasurable object for the subject.

Applying Rayan's and Rigby's concept (2010), video game gives a large space to fulfill human desires relating to the freedom (autonomy) and relatedness. Autonomy allows the player creating his own character and deciding the story line in video game repeatedly as a result the ideal full form can be constructed and reconstructed until the "perfect" line. Whereas, in the relatedness concept, video game gives space that allows human to be connected. However, this connection at the end is not only created between human to human but also to the artificial intelligence, a relation that can be constructed to get the desire of having and desire of being.

Although there is limitation in this study especially relating to the data availability and references, it is expected that this study can contribute to new media research that focuses on study of video game. At the least, in the future, it can be continued with the similar research about psychoanalysis, the relation between video game 
and its player through various disciplines. This study is a part of the author's dissertation titled "Embodiment in Video Game, The Self in The Video Game".

\section{Bibliography}

Aarseth, E. (2004). Genre Trouble: Narrativism and The Art of Simulation. in: WardripFruin, N., Harrigan, P. First Person: New Media as Story, Performance, And Game. Cambridge: The MIT Press.

Baudrillard, J. (1998) The End of the Millennium or the Countdown, Theory, Culture and Society. Sage Publication Journal. Volume: 15 issue: 1, page(s): 1-9 Bernard, H. Russel 1994 "Methods Belong to All of Us", in Robert Borofsky (Trans.) Assessing Cultural Anthropology. New York: McGraw-Hill.

Bracher, M. (2003). Jacques Lacan, Diskursus, dan Perubahan Sosial: Pengantar kritik budaya psikoanalisis. Trans. Gunawan Admiranto. Yogyakarta: Jalasutra.

Bogost, I. (2010). Persuasive Games. Cambdrige and London: MIT Press. .

Caillois, R. (1961) Man Play and Games. Trans. Meyer Barash. London: The Free Press of Glencoe, Inc. Cassell, J., Jenkins, H. (2008). From Quake Girls to Desperate Housewives: A Decade of Gender and Computer Games. In: Kafai, Y Et Al. Beyond Barbie \& Mortal Kombat: New Perspectives on Gender and Gaming. Cambridge and London: The MIT Press. Flitterman-Lewis, Sandy. (2005). Psychoanalysis, Film, and Television. Dalam: Allen, R. C. 9ed), "Channels of Discourse. Television and Contemporary Criticism". New York and London: The University of Carolina Press.

Fron, J Et Al. (2007) The Hegemony of Play. Presented in The Situated Play. Digital Games Research Conference. Tokyo.

Freud, S. (1963). Character and Culture: Vol. 9. The Collected Works. (P.
Rieff, Ed.). New York: Collier. Goldstein, J. (2005). Violent Video Games. In: Raessens, J., Goldstein, J. Handbook of Computer Game Studies. Cambridge and London: The MIT Press. Griffiths, M., Davies, M. (2005). Does Video Game Addiction Exist? In: Raessens, J., Goldstein, J. (2005). Handbook of Computer Game Studies. Cambridge and London: The MIT Press. Harrigan, P., Wardrip-Fruin, N., Crumpto, M., (2010). Second Person: Role-Playing and Story in Games and Playable Media. Cambridge: MIT Press. Hepburn, A. (2003). An Introduction to Critical Social Psychology. London: Sage Publication.

Huizinga, J. (1955) Homo Ludens: A Study of the Play Element in Culture. London: Beacon Press. Juul, J. (2009). A Casual Revolution: Reinventing Video Games and Their Players. Cambridge and London: The MIT Press.

Kafai, Y Et Al (2008). Preface: Pink, Purple, Casual or Mainstream: Moving Beyond the Gender Divide. In: Kafai, Y Et Al. Beyond Barbie \& Mortal Kombat: New Perspectives on Gender and Gaming. Cambridge and London: The MIT Press.

Kapp, K. (2012). The Gamification of Learning and Instruction: Game Based Methods and Strategies for Training and Education. San Fransisco: Pfeiffer.

Kirkpatrick, G. (2009). "Controller, Hand, Screen: Aesthetic Form in the Computer Game". Games and Culture. London: Sage Publication.

Lacan, J. (1977). Ecrits: A Selection. New York: W.W.Norton

Lacan, J. (1977). The Four Fundamentals of Psychoanalysis. London: Hogarth Press.

Lacan, J (1997). The Language of the Self: The Function of Language in Psychoanalysis. Translated by Anthoni Wilden. Baltimore: John Hopkins University Press. Mayra, F. (2008). An Introduction to Game 
Studies. Padston: Sage Publication.

Metz, C. (1982). The Imaginary Signifier: Psychoanalysis and the Cinema. Bloomington: Indiana University Press.

Paiton, M. Q. (2001). Purposeful Sampling. In Alan Bryman (ed), Ethnography, Volume II. London: Sage Publication.

Rigby, S., Ryan, R. (2011). Glued to Games: How Video Games Draw Us in and Hold Us Spellbound. Santa Barbara: Praeger. Saukko. Paula. 2003. Doing Research in Cultural Studies: An Introduction to Classical and New Methodological Approaches (Introducing Qualitative Methods series). London. Sage Publication Inc.

Salen, K., Zimmerman, E. (2006). The Game DesignReader:ARuleofPlayofAnthology. Cambridge and London: The MIT Press.

Spradley, James P. 1997. Metode Etnografi. Yogyakarta. Tiara Wacana Yogyakarta.
Rodriguez, Hector (2006). The Playful and the Serious: An approximation to Huizinga's HomoLudens', GameStudies.(6)1, dalam http://gamestudies.org/0601/articles/ rodriges (diakses pada 8/12/2016 15:20)

Ruti, M. (2010). "The Singularity of Being: Lacan and the Immortal Within". Journal of the American Association Psychoanalytic, Vol. 58, No. 6. Vasseleu, C. (1991). "The Face before the Mirror-Stage". Hypatia, Vol. 6, No. 3.

Wijaya, B.S. (2015). "Desire and Pleasure in the Branded Reality Show as a Discursive Psychoanalysis". Jurnal Humaniora, Vol. 27 No. 1, pp. 2741. DOI 10.22146/jh.v27i1.6406

W. R. (1835). "The Pleasures of Hope". The Dublin Penny Journal, Vol. 4, No. 177 